\title{
Characterization of tri
} CrossMark and tetra-nucleotide microsatellite loci for the freshwater snails Promenetus exacuous (Planorbidae) and Valvata tricarinata (Valvatidae) and their utility in population genetic studies

\author{
Patrick Yurco and Devon B. Keeney* (1)
}

\begin{abstract}
Objective: Promenetus exacuous and Valvata tricarinata are freshwater snail species with widespread distributions throughout North America. Information regarding their genetic diversity and population connectivity are currently lacking. We utilized next generation sequencing to develop the first microsatellites for each species to investigate genetic diversity within and differentiation among populations.

Results: Sixteen and seventeen microsatellite loci were developed for P. exacuous and $V$. tricarinata, respectively, and tested in a total of 43 P. exacuous and $48 \mathrm{~V}$. tricarinata from two lakes approximately $183 \mathrm{~km}$ apart in New York State, USA. Fifteen P. exacuous loci were polymorphic in at least one lake and possessed 1-23 alleles and observed heterozygosities of $0.00-0.96$ within individual lakes. Seventeen polymorphic $V$. tricarinata loci possessed 2-19 alleles and observed heterozygosities of 0.04-0.96 within lakes. Bayesian clustering using 12 loci for each species identified two distinct genetic populations, reflecting the two lakes. High assignment scores for individual snails to the lakes they were collected from supported strong population structure with minimal admixture at the scale of this study. These loci will be useful for investigating the genetic diversity and population structure of these species and indicate genetic differentiation may be common among their populations.
\end{abstract}

Keywords: Microsatellite loci, Promenetus exacuous, Valvata tricarinata, Population genetics, Gastropod genetic diversity

\section{Introduction}

Despite their diversity, importance to ecosystems, and conservation concerns, basic taxonomic and biological information is lacking for many freshwater gastropods throughout North America [1, 2]. We report here the development of independent sets of 16 and 17 microsatellite loci for two understudied species of freshwater

\footnotetext{
${ }^{*}$ Correspondence: keeneydb@lemoyne.edu Department of Biological and Environmental Sciences, Le Moyne College, 1419 Salt Springs Road, Syracuse, NY 13214-1301, USA
}

gastropods, Promenetus exacuous (Say, 1821) and Valvata tricarinata (Say, 1817). Microsatellites were developed for these particular species for future studies comparing their genetic connectivity throughout New York State based on the species' disjunct and often sympatric populations throughout the region, their phylogenetic divergence and differing biological characteristics offering comparative insights into gastropod population connectivity throughout New York, and their current lack of genetic data and available microsatellite loci [3]. In addition, both species have widespread distributions 
throughout North America and secure global conservation status with localized areas of concern, potentially increasing the interest of these microsatellites to other researchers [4-6].

\section{Main text}

\section{Materials and methods}

Valvata tricarinata and P. exacuous were collected from Round Lake ( $\left.43^{\circ} 02^{\prime} 55.6^{\prime \prime} \mathrm{N}, 75^{\circ} 58^{\prime} 24.1^{\prime \prime} \mathrm{W}\right)$ and Lake Saratoga $\left(43^{\circ} 03^{\prime} 12.6^{\prime \prime} \mathrm{N}, 73^{\circ} 43^{\prime} 11.8^{\prime \prime} \mathrm{W}\right)$ using dip nets. Both lakes are in New York State and are approximately $183 \mathrm{~km}$ apart. To develop microsatellite loci, genomic DNA for next generation sequencing was extracted from the foot of a single $V$. tricarinata from Round Lake and a single $P$. exacuous from Lake Saratoga using a Qiagen Dneasy ${ }^{\circledR}$ Tissue kit. DNA was eluted with $75 \mu \mathrm{H}_{2} \mathrm{O}$ and quantified using a NanoDrop 2000 (Thermo Scientific). Approximately $3 \mu \mathrm{g}$ of RNA-free genomic DNA from each species was sent to the University of WisconsinMadison Biotechnology Center for DNA fragmentation and sequencing. Next generation sequencing was performed using an ION Torrent PGM system with each species allocated approximately $25 \%$ of a 318 chip. Raw genomic data were converted to FASTA format using Geneious ver. 8.1 [7]. Microsatellite motifs were identified using msatcommander 1.0.8 [8]. Parameters were set to search for perfect tri- and tetranucleotide repeats with a minimum length of eight repeat units to decrease the potential for genotyping errors due to stuttering common with dinucleotide repeats, and increase the likelihood of polymorphism $[9,10]$. Primer $\% G C$ was set to $35-65 \%$, optimal annealing temperature was $60{ }^{\circ} \mathrm{C}$, and one primer from each pair was designed to have a $5^{\prime} \mathrm{CAG}$ tag (CAGTCGGGCGTCATCA) (Table 1). Default settings were used for the remaining parameters.

DNA was extracted from 24 $V$. tricarinata snails from each lake and 24 and 19 P. exacuous from Round Lake and Lake Saratoga, respectively. For each DNA extraction, the foot was removed and transferred to $400 \mu \mathrm{l}$ of $5 \%$ Chelex containing $0.1 \mathrm{mg} / \mathrm{ml}$ proteinase $\mathrm{K}$. The solution was incubated for approximately $8 \mathrm{~h}$ at $60{ }^{\circ} \mathrm{C}$ followed by eight minutes at $95^{\circ} \mathrm{C}$. DNA was utilized directly from these extractions. Microsatellite loci were amplified using three primer polymerase chain reactions (PCRs) [11] on individual loci with the Qiagen Type-it Microsatellite Kit. Each $10 \mu \mathrm{l}$ reaction included $1 \mathrm{X}$ Type-it Multiplex PCR (Qiagen) reaction mix, $0.2 \mu \mathrm{M}$ standard locus primer, $0.02 \mu \mathrm{M}$ locus primer with CAG tag sequence, and $0.2 \mu \mathrm{M}$ fluorescent-labeled CAG tag (PET, NED, 6-FAM, or VIC). The parameters of the PCRs were 5 min heat activation at $95{ }^{\circ} \mathrm{C}$ followed by 30 cycles of denaturation at $95{ }^{\circ} \mathrm{C}$ for $30 \mathrm{~s}$, annealing for $90 \mathrm{~s}$, and an extension at
$72{ }^{\circ} \mathrm{C}$ for $30 \mathrm{~s}$. The 30 cycles were followed by a final extension of $30 \mathrm{~min}$ at $60{ }^{\circ} \mathrm{C}$. An initial round of PCRs was performed with a gradient of annealing temperatures ranging from 50 to $70{ }^{\circ} \mathrm{C}$ to determine optimal annealing temperatures. All optimized loci utilized an annealing temperature of $60{ }^{\circ} \mathrm{C}$, except Pex1877 and Pex2263 $\left(56{ }^{\circ} \mathrm{C}\right)$, and Pex $216\left(53{ }^{\circ} \mathrm{C}\right)$. Genotypes were determined on an ABI $3730 \times 1$ 96-capillary Genetic Analyzer at the DNA Analysis Facility at Yale University. PCR products from up to four loci utilizing different fluorescent dyes were combined in each well prior to submission. Alleles were scored using Geneious ver. 8.1 [7].

MICRO-CHECKER ver. 2.2 [12] was used to identify potential scoring errors from stuttering, large allele dropout, and/or the presence of null alleles. Alleles were analyzed for deviations from Hardy-Weinberg expectations within sites and overall linkage disequilibrium using Genepop on the Web [13, 14]. Significance tests with multiple comparisons used an adjusted critical value based on the B-Y False Discovery Rate (FDR) [15]. STRUCTURE ver. 2.4.3 [16] was used to determine if loci could infer population differentiation by using genotypes to assign individuals to genetic clusters and estimate the actual number of genetic populations using a Bayesian approach. A highly conservative subset of twelve loci for each species that did not display deviations from Hardy-Weinberg expectations in either site, did not include loci displaying linkage with each other, and that failed to amplify in no more than two snails in either population (P. exacuous: Pex577, Pex757, Pex1009, Pex1877, Pex2091, Pex2181, Pex2263, Pex2471, Pex2889, Pex2908, Pex2958, and Pex2972; V. tricarinata: Vtr99, Vtr565, Vtr828, Vtr835, Vtr980, Vtr1099, Vtr1279, Vtr2328, Vtr2388, Vtr2492, Vtr4154, and Vtr4287) were used for STRUCTURE analyses. STRUCTURE runs used an admixture model with five iterations, a burnin length of 100,000 and 100,000 steps in the Monte Carlo Markov Chain (MCMC). Separate runs for each species utilized LnPD as the selection criterion and the number of genetic populations (K) was allowed to range from 1 to 6 .

\section{Results and discussion}

Fifteen polymorphic $P$. exacuous loci possessed 1-23 alleles and observed heterozygosities ranged from 0.00 to 0.96 within individual lakes (Table 1 ). One locus deviated from Hardy-Weinberg expectations in Round Lake (Pex2117), potentially from null alleles and/or stuttering issues. Null alleles may also be present in Pex216 and Pex2117 in Lake Saratoga, with low amplification success likely prohibiting statistical significance. An additional sixteenth locus (Pex2416) was 


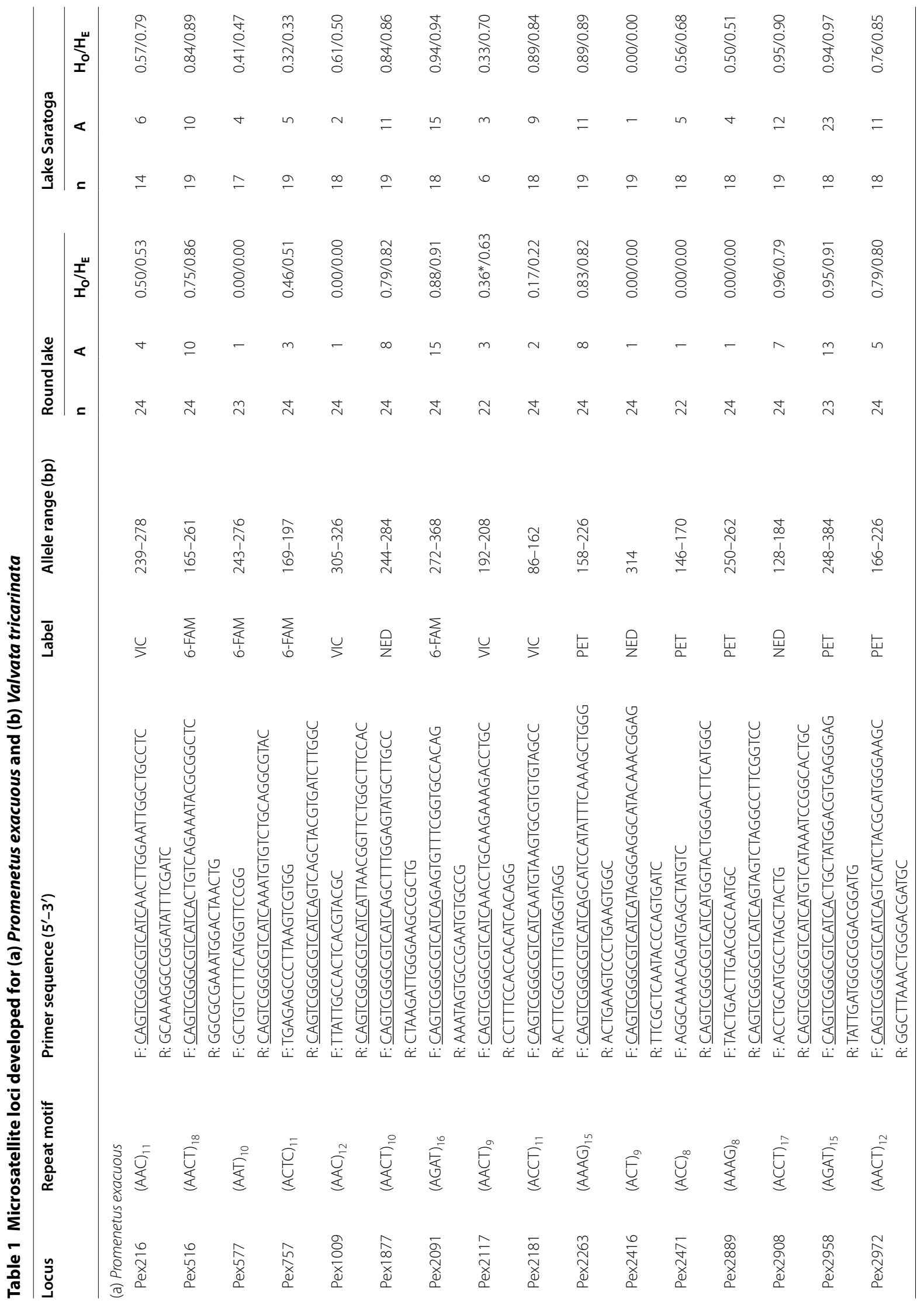




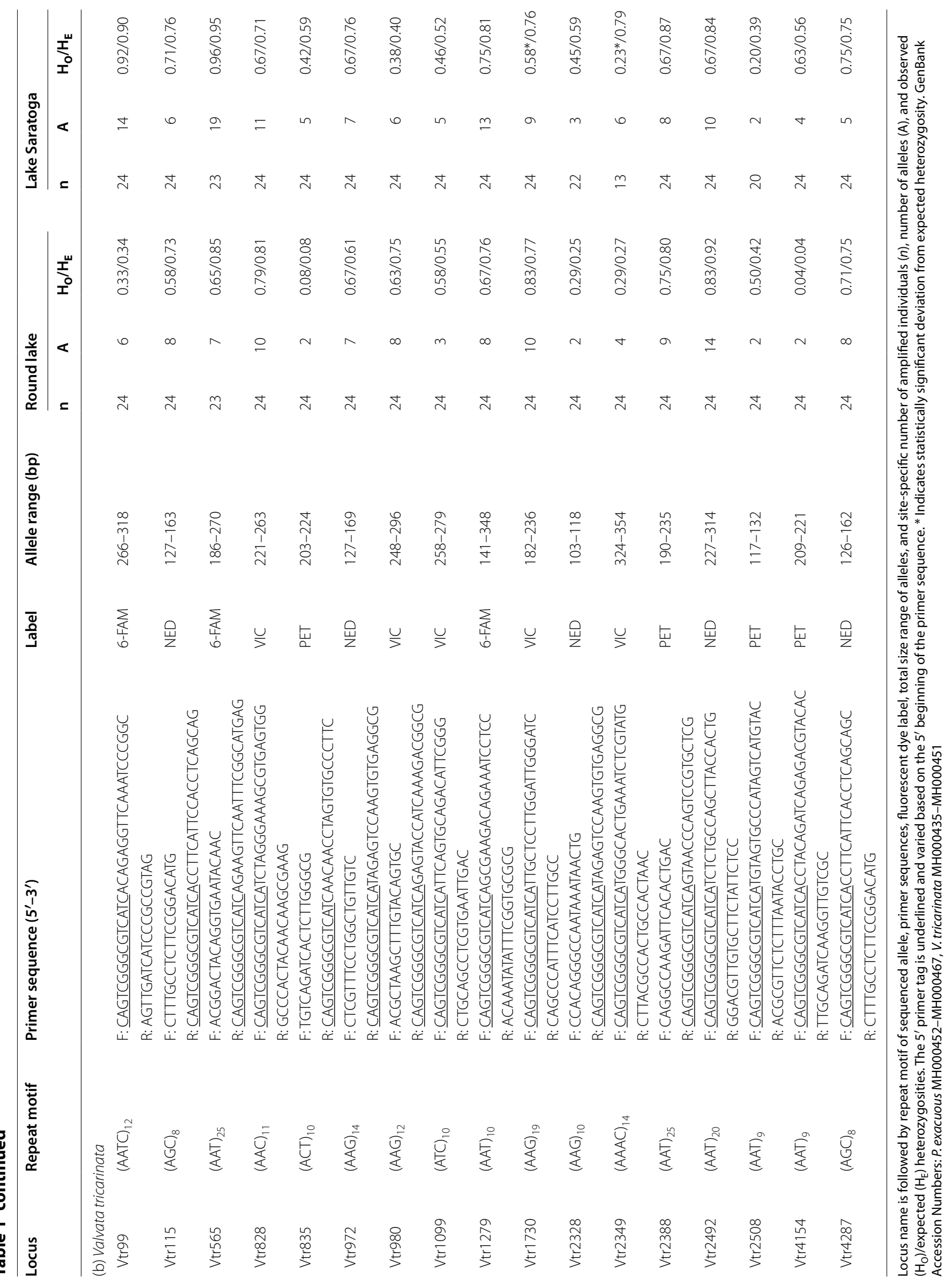


monomorphic in both populations, but is reported here as it may be polymorphic in other populations as observed between populations with several similar loci in the present study. Linkage disequilibrium was not detected between any pair of P. exacuous loci.

Seventeen polymorphic $V$. tricarinata loci possessed 2-19 alleles and observed heterozygosities of 0.04-0.96 within lakes (Table 1). Two loci deviated from HardyWeinberg expectations in Lake Saratoga (Vtr1730 and Vtr2349), potentially due to null alleles. Null alleles may also be present in Vtr2508 in Lake Saratoga. Linkage disequilibrium was detected among Vtr115, Vtr972, and $\operatorname{Vtr} 4287$.

STRUCTURE results for both species supported two genetic populations $(K=2)$, reflecting the two sample locations (Fig. 1). All snails were assigned to the population they were sampled from with a high probability (97-100\% for all snails except a single $V$. tricarinata from Lake Saratoga with 92\%), revealing minimal admixture between these populations for both species (Fig. 1). The high assignment values reveal that these loci will be suitable for identifying gene flow patterns among populations experiencing varying levels of admixture. Multiple genetic groups were not detected within sites.

The development of microsatellites in these two understudied, distantly related species will enable researchers to examine the factors impacting the genetic diversity within and population structure among their populations, and gain additional insights into the biology, evolution, and conservation of freshwater gastropods. While our interests are primarily the dispersal and connectivity of these species throughout New York State and surrounding areas, these microsatellites may be used by other labs to address diverse questions in other regions. For example, although both species are globally secure, there are conservation concerns for specific populations throughout their range [4-6], and these markers may aid in conservation efforts. In addition, direct comparison of gastropods from different families over large geographic areas may reveal broad evolutionary dispersal patterns.

\section{a Promenetus exacuous}

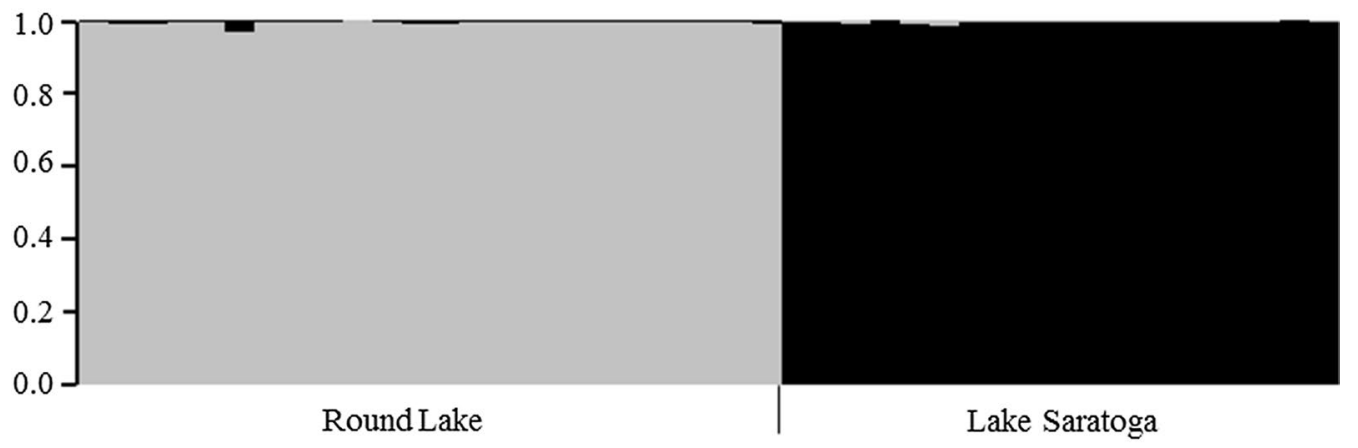

b Valvata tricarinata

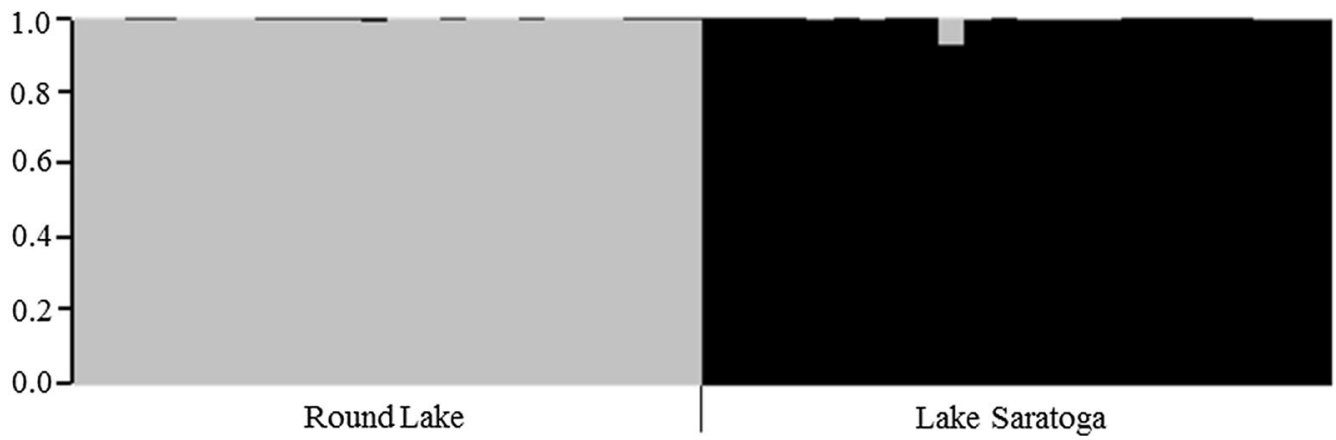

Fig. 1 Results of STRUCTURE cluster membership analyses for $\mathbf{a}$ Promenetus exacuous and $\mathbf{b}$ Valvata tricarinata for $\mathrm{K}=2$. Vertical bars represent proportion of membership of individual snails for two genetic clusters (gray= Round Lake, black= Lake Saratoga). Labels below graphs indicate original sample sites 


\section{Limitations}

Due the potential for variation in regions flanking microsatellite loci and the relatively widespread distribution of both species, some of these loci may not amplify in populations throughout their range.

\author{
Abbreviations \\ PCR: polymerase chain reaction; FDR: false discovery rate; $K$ : number of \\ genetic populations; NCBI: National Center for Biotechnology Information; $n$ : \\ number of amplified individuals; $\mathrm{A}$ : number of alleles; $\mathrm{H}_{\mathrm{O}}$ : observed heterozy- \\ gosity; $\mathrm{H}_{\mathrm{E}}$ : expected heterozygosity.
}

\section{Authors' contributions}

PY and DBK participated in all aspects of data collection, data analyses, and manuscript preparation. Both authors read and approved the final manuscript.

\section{Acknowledgements}

The author(s) thank the University of Wisconsin Biotechnology Center DNA Sequencing Facility for providing next generation genomic DNA sequencing facilities and services and Yale University's DNA Analysis Facility on Science Hill for genotyping services.

\section{Competing interests}

The authors declare that they have no competing interests.

\section{Availability of data and materials}

The microsatellite sequences generated from this study are available through NCBI's GenBank (https://www.ncbi.nlm.nih.gov/nucleotide/) and are accessible via the GenBank Accession Numbers MH000435-MH000467).

\section{Consent for publication}

Not applicable.

\section{Ethics approval and consent to participate}

All applicable national, international, state, and institutional guidelines for the care and use of animals were followed. Collection permits were obtained from the New York Department of Environmental Conservation (\#1674) and New York State Office of Parks, Recreation and Historic Preservation (\#2011-GL-006).

\section{Funding}

Funding was provided by Le Moyne College's Research and Development Committee.

\section{Publisher's Note}

Springer Nature remains neutral with regard to jurisdictional claims in published maps and institutional affiliations.

Received: 8 February 2018 Accepted: 20 March 2018

Published online: 27 March 2018
References

1. Perez KE, Minton RL. Practical applications for systematics and taxonomy in North American freshwater gastropod conservation. J N Am Benthol Soc. 2008;27:471-83.

2. Johnson PD, Bogan AE, Brown KM, Burkhead NM, Cordeiro JR, Garner JT, Hartfield PD, Lepitzki DAW, Mackie GL, Pip E, Tarpley TA, Tiemann JS, Whelan NV, Strong EE. Conservation status of freshwater gastropods of Canada and the United States. Fisheries. 2013;38:247-82.

3. Jokinen EH. The freshwater snails (Mollusca: Gastropoda) of New York State. New York: State Museum Bulletin; 1992. p. 482.

4. Sutter JV, Andersen ME, Bunnell KD, Canning MF, Clark AG, Dolsen DE, Howe FP. Utah comprehensive wildlife conservation strategy (CWCS). Salt Lake City: Utah Division of Wildlife Resources; 2005.

5. Pyron M, Beugly J, Martin E, Spielman M. Conservation of the freshwater gastropods of Indiana: historic and current distributions. Am Malacol Bull. 2008;26:137-51.

6. Natureserve. NatureServe Explorer: An online encyclopedia of life. Version 7.1. NatureServe, Arlington, Virginia. 2017. http://explorer.natureserve.org. Accessed 11 Jan 2018.

7. Kearse M, Moir R, Wilson A, Stones-Havas S, Cheung M, Sturrock S, Buxton S, Cooper A, Markowitz S, Duran C, Thierer T, Ashton B, Mentjies P, Drummond A. Geneious basic: an integrated and extendable desktop software platform for the organization and analysis of sequence data. Bioinformatics. 2012;28:1647-9.

8. Faircloth BC. MSATCOMMANDER: detection of microsatellite repeat arrays and automated, locus-specific primer design. Mol Ecol Resour. 2008:8:92-4.

9. Buschiazzo E, Gemmell NJ. The rise, fall and renaissance of microsatellites in eukaryotic genomes. BioEssays. 2006;28:1040-50.

10. Zalapa JE, Cuevas H, Zhu H, Steffan S, Senalik D, Zeldin E, Mccown B, Harbut $R$, Simon P. Using next-generation sequencing approaches to isolate simple sequence repeat (SSR) loci in the plant sciences. Am J Bot. 2012:99:193-208.

11. Schuelke M. An economic method for the fluorescent labeling of PCR fragments. Nat Biotechnol. 2000;18:233-4.

12. Van Oosterhout C, Hutchinson WF, Wills DPM, Shipley P. MICRO-CHECKER: software for identifying and correcting genotyping errors in microsatellite data. Mol Ecol Notes. 2004;4:535-8.

13. Raymond M, Rousset F. GENEPOP (version 1.2): population genetics software for exact tests and ecumenicism. J Hered. 1995:86:248-9.

14. Rousset F. Genepop'007: a complete reimplementation of the Genepop software for Windows and Linux. Mol Ecol Resour. 2008:8:103-6.

15. Narum SR. Beyond Bonferroni: less conservative analyses for conservation genetics. Conserv Genet. 2006;7:783-7.

16. Pritchard JK, Stephens M, Donnelly P. Inference of population structure using multilocus genotype data. Genetics. 2000;155:945-59.

\section{Submit your next manuscript to BioMed Central and we will help you at every step:}

- We accept pre-submission inquiries

- Our selector tool helps you to find the most relevant journal

- We provide round the clock customer support

- Convenient online submission

- Thorough peer review

- Inclusion in PubMed and all major indexing services

- Maximum visibility for your research

Submit your manuscript at www.biomedcentral.com/submit
C Biomed Central 